\title{
DEATH AND MEMORY AT THE MONASTERY: PRIVILEGED BURIALS AND THEIR PATRONS IN THE NEWLY FOUNDED KINGDOM OF PORTUGAL
}

JORGE RODRIGUES

UDC: $27-788(469) " 10 / 12 "$ 27-552(469)"10/12"

Original scientific paper

Manuscript received: 09. 12. 2016.

Revised manuscript accepted: 27. 02. 2017.

DOI: 10.1484/J.HAM.5.113747

\author{
J. Rodrigues \\ IHA/DHA [Art History Institute/Department] \\ FCSH-Universidade NOVA de Lisboa and Calouste Gulbenkian Museum \\ Rua da Milharada, 23-8을 Diro \\ 2745-822 Queluz, Portugal \\ jrodrigues@gulbenkian.pt
}

This paper aims to establish the artistic and symbolical context associated with the evolution of the architectonically structured burial spaces in the newly founded kingdom of Portugal, between the end of the $11^{\text {th }}$ and the early years of the $13^{\text {th }}$ centuries, with an emphasis on monastic institutes and the transport of its models from beyond the Pyrenees, crossing through the peninsular kingdoms and finally arriving to Portugal. The examples of the first galilee named as such - that of Cluny II - was followed by those of Romainmôtier, Tournus, León or Sahagún. We successively approached the first type of pantheons identified in Portugal - that of the galilees which precede the temple, used by their founders - concentrating initially on the first royal pantheon of Santa Cruz in Coimbra, and subsequently trying to understand how this model was used in a vast group of burial spaces sponsored by the noble landlords and patrons of the Church, following the territorial expansion of the kingdom but mainly concentrated on its northern territories, around major cities such as Braga or Guimaräes, relevant towns like Amarante and Oporto, or closer to the borders as in Valença, over the river Minho. Two case studies will best show the use of this model on Portuguese rural Romanesque architecture, either associated to the Augustinians, as in Sáo Pedro of Ferreira, or to the Benedictins, like in Sanfins of Friestas.

Key words: galileelante-church, pantheon, chapel, arcosolium, funerary, privileged burial, sarcophagus, monastery, memory, salvation

\section{THE GALILEE IN ROMANESQUE BURIAL ARCHITECTURE: FROM BURGUNDY TO SPAIN}

The cult of the dead and the idea of the afterlife is a central human obsession from the very first magical-religious practices to the institution of religious rites in Christian faith, aiming not only at the permanence of the immortal soul but also for the Resurrection in the end of times, following Judgement Day. The «overcoming of the idea of death through the triumph of memory over oblivion» ${ }^{1}$ was from very early days related to a new kind of necropolis and monuments, which were associated to the Christian temples and bearing the symbols of the new faith.

The rise and expansion of the Christian «militia» - the monks and their monasteries - and in particular of the Benedictines (and amongst them of the Cluniac, from the $10^{\text {th }}$ century on) - would give a new scope to these religious and symbolic practices. As true «praying factories», the monasteries turn the liturgy of the departed into a privileged form of communication between the living and the dead - in which the first dedicate their lives to prayer in order to obtain from the second their protection in return - with the monks acting as privileged «middlemen» in this bond, made real through the ritual, sometimes with near-magic features ${ }^{2}$. The celebration of memory - and of the monuments, spaces and rituals related to it - was performed in function of the mutual benefit in the relationship between the living and the dead, mediated through ritual by its agents - the priests and monks - and by its devices, including all the scenography associated to the death ceremonial: «Memory is praxis, an active, even interactive process. Monuments designed for the purpose of commemoration utilize many devices to trigger memory: vivid images that are both marvelous and active; strategically placed figurations or inscriptions which contextualize the site; and a kinetic relationship between the funerary monument and its visitors, often manifested in ritual acts involving movement around or in the monument. These memorial strategies established a dialogue between the living and the dead and articulated mutual benefits for both parties»33.

Associated to the temples and to the locus sepulcralis is the memory of their founders and of their lineages, buried as close as possible to these walls in order to emphasize the protection that they anticipated for the salvation of their souls, even before they managed to «conquer» the inner space of the churches for their privileged burials. In fact since 561 and up to the 13th century, complying with the decisions of the Council of Braga, the entombments inside the temples were not tolerated ${ }^{4}$, a fact that is going to constrain in particular the burial of the noblest and richest of the laymen in the church.

The option for their privileged burials will be to search the places nearest the church building, if possible on the outer arch of the chancel, as close as possible to the relics of the martyrs - ad sanctus - or under its eaves - sub stillicidio. When their condition and riches allow, the noblemen and/or the royalty seeks to have their burials in front of the main western door of the temple, the Heaven's Gate, in the space previously defined by the churchyard - ante limina ecclesiae - a metaphor of the soul waiting for Judgement

\footnotetext{
${ }^{1}$ B. SOUSA, D. Afonso IV (1291-1357), Lisboa, 2005, p. 260.

${ }^{2}$ J. MATTOSO, O reino dos mortos na Idade Média Peninsular, Lisboa, 1996, p. 101-102.

3 E. VALDEZ DEL ALAMO, C. PENDERGAST, Memory and the Medieval Tomb, Farnham, 200o, p. 1.

${ }^{4}$ See, amongst others, P. ARIÈS, L'Homme devant la Mort, Paris, 1977, p. 38; J. MACIEL, Antiguidade tardia e paleocristianismo em Portugal, Lisboa, 1996, p. 78; I. BANGO TORVISO, El espacio para enterramientos privilegiados en la arquitectura medieval española, in Anuario del Departamento de Historia y Teoría del Arte, IV, Madrid, 1992, p. 93-132, here p. 94; or X. DECTOT, Les tombeaux des familles royales de la péninsule ibérique au Moyen Âge, Turnhout, 2009, p. 141.
} 


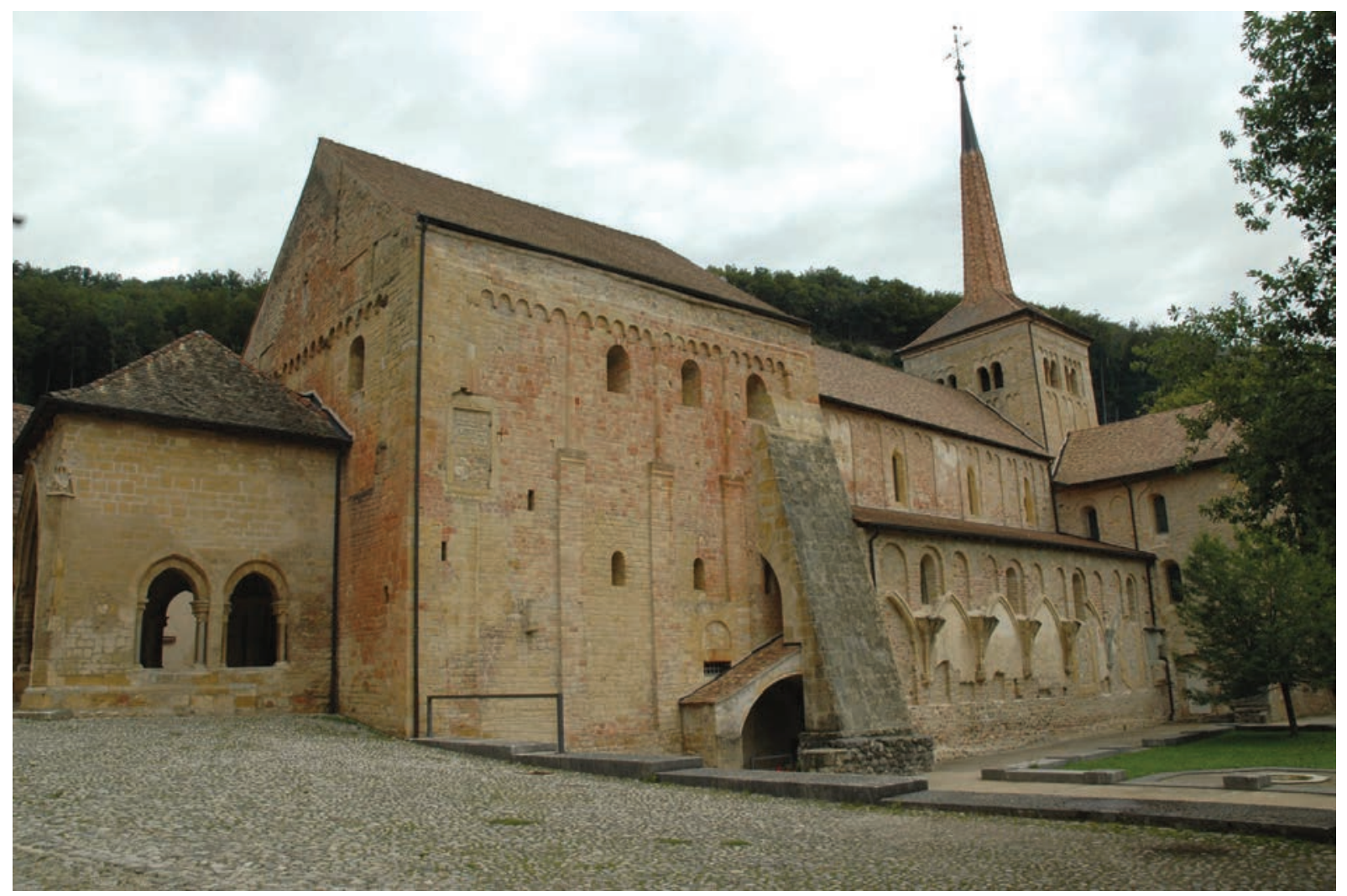

Fig. 1 - Romainmôtier, Switzerland, church and galilee

Day to be admitted into Paradise ${ }^{5}$, resting before its door ${ }^{6}$. It will be on this place that these men will build their funerary structures - the galilees - as the church-before-the-church, getting as close as possible to the Gate of Heaven without antagonizing the Church authorities and their ban of the burials inside the temples.

The exegesis of the word Galilea/galilee is first traced to the translations of the Hebrew names by Saint Jerome, from which Saint Augustin will draw up its figurative sense, later resumed from Gregory the Great by Rupert of Deutz in the $12^{\text {th }}$ century: the funerary liturgy was then centered on the Sunday procession ${ }^{7}$. This procession of the dead is described in Portugal by Fray Leão of S. Tomás when he mentions the Benedictine monastery of Santo Tirso ${ }^{8}$, celebrating the Resurrection of Christ in the monastic churches since the $8^{\text {th }}$ century: after crossing the cloister and the monastic buildings the procession stopped in a solemn station facing the western portal of the church before returning to the choir, with the abbot or the celebrant in the role of Christ, preceding the monks that followed him like the Disciples: «Pour résumer brièvement, on peut dire que l'hébreu galilea, que Jérôme traduit en latin par transmigratio peracta, désigne en premier lieu l'endroit où Jésus avait prédit de rencontrer ses disciples après sa crucifixion et sa résurrection, épisode annoncé dans les évangiles de Marc et Matthieu, mais relaté seulement par Matthieu. Au sens figuré, galilea signifie la transition du judaïsme à la foi chrétienne. Mais, avant tout, il faut entendre par galilea la transition de la mort à la vie éternelle démontré par le Christ ressuscité (...) Enfin, en analogie directe avec la encontre du Christ ressuscité et de ses disciples, galilea désigne le moment après la résurrection des morts à la fin du temps, où les bienheureux accèderont à la vie éternelle et se retrouveront en présence de Dieu (...). On peut donc conclure que la transposition du nom biblique galilée à un endroit précis de la topographie monastique, survenue entre le VIII ${ }^{e}$ et le XII ${ }^{\mathrm{e}}$ siècle, ne s'est pas passé n'importe où ni n'importe quand, mais coïncide avec la construction du premier édifice appelé galilée, c'est-à-dire l'avant- nef de Cluny II, construite sous l'abbé Odilon au débout du XIe siècle»?.

The word galilee applied to an architectural burial structure is therefore first found in the description of the building of the church of Cluny $\mathrm{II}^{10}$, as given by the Liber tramitis, the Cluniac customary, written in the time of Abbot Odilon, between the years of 1027 and 1048. This original galilee, with

${ }_{5}$ A. DIERKENS, Avant-corps, galilées, massifs occidentaux: quelques remarques méthodologiques en guise de conclusions, in Ch. Sapin (dir.), Avant-nefs et espaces d'accueil dans l'église entre le IV et le XII siècle, Paris, 2002, p. 495-503, here p. 498.

${ }^{6}$ Two were of the advantages of being buried in the galilee of the temple: the proximity of the Gate of Heaven and the exposure to the eyes and the compassion of the parayers entering the church precisely through this door, as and «expedient of social prestige and class pride», benefiting, in death, from the "prayers of the living», I. BANGO TORVISO, op. cit. (n. 4), p. 97 and X. DECTOT, op. cit. (n. 4), p. 141-142.

${ }^{7}$ K. KRÜGER, Tournus et la fonction des Galilées en Bourgogne, in Ch. Sapin (dir.), op. cit. (n. 5), p. 414-423, at p. 420, says about the procession: «Au début du XII siècle, Rupert de Deutz donne une interprétation particulière de cette procession, qui emprunte clairement à exégèse du mot galilée. Il souligne que la station devant le portail de l'église se tient en mémoire de la rencontre des disciples avec le Ressuscité, comme le rapporte Matthieu (...). Ensuite, Rupert précise que l'endroit où la station a lieu est appelé par nous la galilée».

${ }^{8}$ L.S. TOMÁS, Benedictina Lusitana, 2 vols., $2^{\text {nd }}$ ed. [facsimile of the $1^{\text {st }}$ ed. Lisboa, 1644-1651; edited by J. Mattoso], II, Lisboa, 1974, p. $43-44$.

9 K. KRÜGER, Architecture and Liturgical Practice: The Cluniac galilea, in N. Hiscock (ed.), The White Mantle of Churches. Architecture, Liturgy, and Art around the Millennium, Turnhout, 2003, p. 139-159, here p. 149-151.

${ }^{10}$ N. HISCOCK, The Ottonian Revival: Church Expansion and Monastic Reform, in N. Hiscock (ed.), op. cit. (n. 9), p. 1-28, here p. 16-17. 
three aisles and three bays, is the contemporary of the very first double storey galilees still surviving today, those of Romainmôtier and Tournus ${ }^{11}$, with Cluny II being destroyed and replaced by the enormous expansion of the new church of Cluny III, consecrated in 1088.

In fact the Swiss abbey of Romainmôtier, consecrated in 1028, had its galilee added to the original church building in around 1060-1070, with a similar structure of three aisles, slightly narrower than the church but here longer than in Cluny II, with four bays covered with groin vaults (fig. 1). The upper storey is accessible through a small door and a spiral staircase that opens to the chapel emulating that of Cluny, dedicated to Saint Michael, the psychopomp Saint. Here, over the crypt - the place where the bodies would be put to rest inside their monuments - was performed the ritual of salvation and elevation of the souls, in a

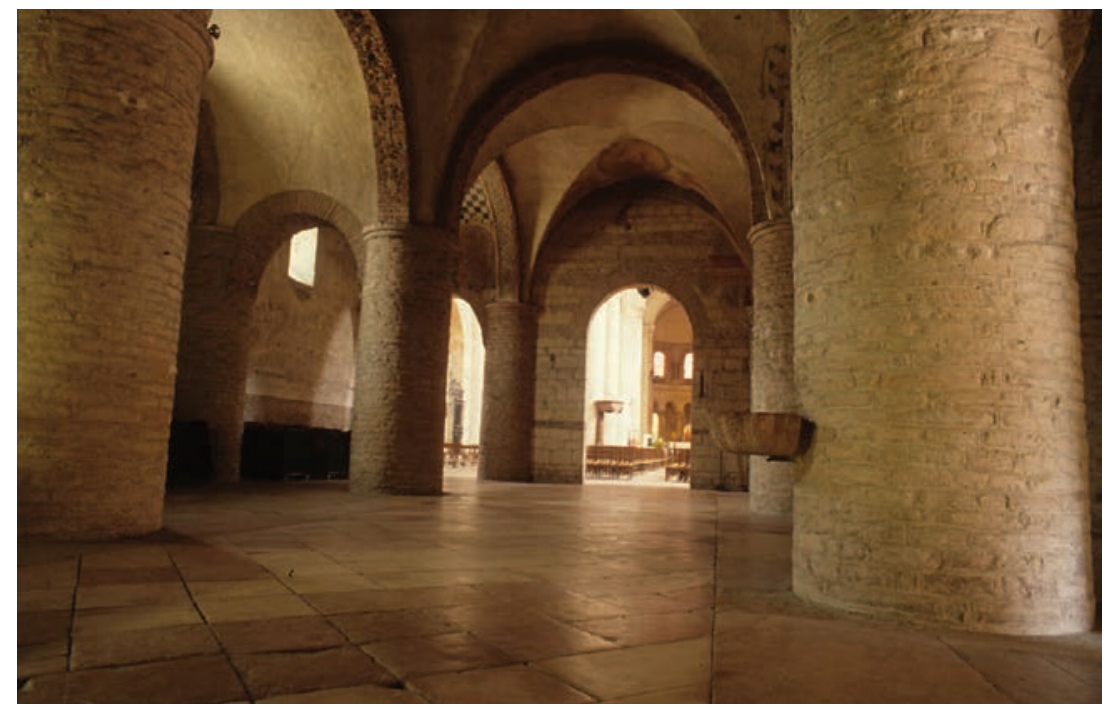

Fig. 2 - Saint-Philibert de Tournus, Burgundy, France, interior of the galilee

settle in one of their first peninsular monasteries, that of San Facundoy Primitivo of Sahagún. Refounded by King Alfonso the $6^{\text {th }}$ before 1080 , in a place where he had already decided to be laid to rest in the galilee of the new church, rededicated now to Saint Benedict, the new monastery would become the main center from where the Gregorian reform would spread throughout Castile and León in the late $11^{\text {th }}$ century, with the enthusiastic patronage of Alfonso the $6^{\text {th }}$, as one of the main benefactors of the Cluniac monks: «Elegí allí el lugar donde descansar tras mi muerte, de manera que lo que había amado extremadamente en vida, yo difunto, también fuese a más ${ }^{18}$.

The galilee of Sahagún continued a Hispanic tradition whose closest parallel was the pantheon of Alfonso's father, Fernando the $1^{\text {st }}$ at San Isidoro de León, rebuilt after the original construction, erected by Afonso the $5^{\text {th }}$ was subjected to subsequent Romanesque transformations by Alfonso the $6^{\text {th }}$, Doña Urraca and Alfonso the $7^{\text {th }}$. Originally dedicated to San Juan Bautista and San Pelayo, San Isidoro de Sevilla would become its Patron Saint after the transference of his relics in 1062, with the new church, «de luto et latere» - of lath and plaster and brick - consecrated in 1063. This would be later replaced by the present building, and whilst the Fernandine church exhibited the same length and width of the Afonsine one, since it was built over the same foundations ${ }^{19}$, the $12^{\text {th }}$ century construction is far longer and wider, as can still see be seen today. Only the pantheon preserved its
The model implemented in Burgundy would arrive at the Iberian Peninsula with the Cluniac monks that would

\footnotetext{
${ }^{" K}$ K. KRÜGER, op. cit. (n. 7), p. 419-420.

${ }^{12}$ Linked to the Paschal cycle - depositio, elevatio e visitatio - as stated by C. HEITZ, A propos de quelques 'Galilées' bourguignonnes, in J. Thirion (dir.), Saint-Philibert de Tournus. Histoire. Archéologie. Art, Tournus, 1995, p. 253-272, here p. 267.

${ }^{13}$ K. KRÜGER, op. cit. (n. 9), p. 152, refering to Cluny II.

${ }^{14}$ J. HENRIET, Saint-Philibert de Tournus. Les campagnes de construction du XIe siècle, in J. Thirion (dir.), op. cit. (n. 12), p. 177-203, here p. 179.

${ }^{15}$ C. SAPIN, Saint-Philibert et les dábuts de l'architecture romane en Bourgogne, in J. Thirion (dir.), op. cit. (n. 12), p. 215-230, here p. 226.

${ }^{16}$ W. BERRY, Le système de voûtement de la nef de Saint-Philibert de Tournus dans son contexte régional, in J. Thirion (dir.), op. cit. (n. 12), p. 297-321, here p. 299; J. HENRIET, op. cit. (n. 13), p. 177, 193-194, 197; K. KRÜGER, op. cit. (n. 9), p. 141.

${ }_{17}$ Ch. SAPIN, op. cit. (n. 14), p. 216-217 and 225.

${ }^{18}$ Founded over a «cella memoriae» where the relics of Saints Facundo and Primitivo, martyrs, where worshiped, it was the work of Abbot Bernardo de Sauvetat after is arrival from Cluny, in 1080, as one of the leading figures of the Gregorian reform in the Hispania: "Al igual que Cluny destaca en Francia, este monasterio sobrepasa a todos los de su orden en España”», I. BANGO TORVISO, El Camino de Santiago, Madrid, 1993, p. 266; C. COSMEN ALONSO, M. HERRÁEZ ORTEGA, M. VALDÉS FERNANDEZ, Alfonso VI y el monasterio de Sahagún. Nuevos testimonios sobre la construcción del templo monástico, in De Arte. Revista de Historia del Arte, 5, León, 2006, p. 29-41.

${ }^{19}$ X. DECTOT, op. cit. (n. 4), p. 139; J. SENRA GABRIEL Y GALÁN, Les massifs occidentaux des églises dans les royaumes du Nord-Ouest de la Péninsule Ibérique, in Ch. Sapin (dir.), op. cit. (n. 5), p. 336-350, here p. 338-339; G. BOTO VARELA, Morfogénesis de las primeras arquitecturas de San Isidoro. Vestigios de la memoria dinástica leonesa, in P.L. Huerta (org.), Siete maravillas del románico español (org.), Aguilar de Campoo, 20o9, p. 153-191, namely p. $165-166$ and $170-172$.
} 
original space, divided into 3 aisles and probably 3 bays (only 2 survive today), vaulted and decorated with $12^{\text {th }} \mathrm{c}$. fresco paintings, with a new altar dedicated to Saint Catherine but preserving the upper storey, that could have had an aulic function like in Aquisgrana - an upper tribune connected to the nearby royal palace - or, most likely, a ritual function as chapel of the dead, like in Cluny II or Tournus ${ }^{20}$.

\section{THE KINGDOM OF PORTUGAL AND ITS FIRST ROYAL PANTHEON ON ITS FIRST CAPITAL-CITY: THE MONASTERY OF SANTA CRUZ OF COIMBRA}

In Portugal, a County of Burgundian influence since the coming, as a noble without title and land - a true crusader of Henry of Burgundy, the $4^{\text {th }}$ son of the Duke of Burgundy but also great-grandson of Robert I of France, nephew of the Queen Constance of León and nephew-grandson of the Cluniac abbot Hugo of Sémur, the Burgundian influences - and namely those from Cluny - start with the foundation, near Oporto, of the Cluniac monastery of São Pedro de Rates by a group of monks from La Charité-sur-Loire in 1096 , built on the site of a previous «countal» construction of controversial chronology ${ }^{21}$.

His son Afonso Henriques would become Afonso the $1^{\text {st }}$ after the proclamation of the Kingdom of Portugal, in the aftermath of the victory over the Moors at the Battle of Ourique, around 1139, a title first recognized by King Afonso the $7^{\text {th }}$ of Castile and León in the Conference of Zamora in 1143, and later confirmed de jure by Pope Alexander the $3^{\text {rd }}$ through the Bula Manifestis Probatum of $1179^{22}$. Concerned with the preservation of his memory - that, at the time, was also the memory of the young kingdom - Afonso Henriques would be the first one to found a monastery with a burial structure associted, in what was then the capital-city of a realm that spread from the Minho river, on the border with the Leonese Galicia, and the Mondego river, that bathed the city in the Portuguese midlands, with the southern territories still in possession of the Muslims up to the conquest of Lisbon and the Tejo river, taking place only between 1147 and
$1148^{23}$, the final turning point on the war for the reconquest.

The monastery of Santa Cruz [Holy Cross] of Coimbra was founded thanks to a first donation of Afonso Henriques, dating from the $9^{\text {th }}$ of December 1130, with the first stone laid in June the $28^{\text {th }} 1131^{24}$. Afonso Henriques will entrust the monastery to the Portuguese Augustinians, in an agreement made with D. Telo Odores, a cultivated and travelled man that had been to the Holy Land ${ }^{25}$, although his first abbot will be D. Teotónio, which, after a controversial choice, will lead a community of 72 regular canons from the $24^{\text {th }}$ of February $1132^{26}$. D. Telo will die in 1136 but the monastery and the order will thrive in the newly founded kingdom with the inescapable support of the canon D. João Peculiar, future bishop of Oporto and Braga, undoubtedly one of the most prominent characters of the Portuguese church and politics at the time, up to his death in 1175, after a long and successful career that would lead him to the prestigious title of Primaz of the Spains, after occupying the Braga archbishopric in 1138.

From the very start, Santa Cruz of Coimbra would be closely linked to the monastery of Saint Rufus of Avignon, whose Augustinian rule and customary would inspire those of the Portuguese house ${ }^{27}$. The church itself would take several years to complete, with the chancel probably finished by $1136^{28}$, the side altar of the Holy Spirit consecrated by D. João Anaia around 1148 and the High altar consecrated around 1150 by the then already archbishop of Braga D. João Pecu$\operatorname{liar}^{29}$. Afonso Henriques would assume his role of protector and patron of the monastery between 1156 and $1157^{30}$. The prestige of the Augustinian house will be greatly enhanced by the proclamation of the monarch as his founder in a letter sent to Pope Adrian the $4^{\text {th }}$, on this period, stating for the first time his desire to have his burial on its premises, but also that the prayers of the Augustinian canons would contribute for the salvation of his soul; in another letter, this time addressed to Pope Alexander the $3^{\text {rd }}$, he will place himself as the eternal protector of the monastery ${ }^{31}$.

The above mentioned donations, alongside the assumption of Afonso's foundational and protective roles had a double purpose: to ensure his burial - and that of

\footnotetext{
${ }^{20}$ I. BANGO TORVISO, op. cit. (n. 4), p. 104; M. VALDÉS FERNÁNDEZ, El Panteón Real de la Colegiata de San Isidoro de León, in Maravillas de la España medieval. Tesoro sagrado y monarquía, I, León, 2001, p. 73-84; C. ABAD CASTRO, Espacios y capillas funerárias de carácter real, in Maravillas de la España medieval, op. cit. (n. 20), I, p. 63-71, here p. 64; J. SENRA GABRIEL Y GALÁN, op. cit. (n. 19), p. 338-339; X. DECTOT, op. cit. (n. 4), p. 123-124 e 126-128; G. BOTO VARELA, op. cit. (n. 19), p. 176-177.

${ }^{21}$ M. REAL, O Românico Condal em S. Pedro de Rates e as transformações beneditinas do séc. XII, Póvoa de Varzim, 1982, p. 8-9 and 12, 1096 being the date of the act of consecration of the new church, built over the remains of a former temple founded by the earlier counts of Portucale, as shown by J. GOMES, D. CARNEIRO, Escavações arqueológicas na área envolvente à igreja de S. Pedro de Rates 1997-1998, in Póvoa de Varzim. Boletim Cultural, XXXVIII, Póvoa de Varzim, 2003, p. 205-292.

${ }_{22}^{2}$ J. MATTOSO, História de Portugal, II, Lisboa, 1992-1994, p. 62; C. FERNANDES, Efígie de um monarca (D. Afonso Henriques?), in Construindo a Memória. As colecções do Museu Arqueológico do Carmo, Lisboa, 2005, p. 338 and 340.

${ }^{23}$ J. MATTOSO op. cit. (n. 22), II, p. 75-76.

${ }^{24}$ S. GOMES, Os Panteões Régios Monásticos Portugueses nos séculos XII e XIII, in Actas do 2º Congresso Histórico de Guimarães, vol. 4, Guimarães, 1996, p. 280-295, p. 153 and 284; A. GONÇALVES, Estudos de História da Arte Medieval, Coimbra, 1980, p. 161-168, namely p. 161.

${ }_{25}^{25}$ A. FRIAS, O Mosteiro de Santa Cruz de Coimbra, génese e consolidação do projecto canonical, in J. Costa (ed.), Santa Cruz de Coimbra. A cultura portuguesa aberta á Europa na Idade Média, Porto, 2001, p. 15-28, p. 15; A. CRUZ, D. Teotónio, Prior de Santa Cruz. O primeiro Cruzado e primeiro Santo de Portugal, in Santa Cruz de Coimbra. Do século XI ao século XX, Coimbra, 1984, p. 21-58, here p. 32.

${ }^{26}$ S. GOMES, In Limine Conscriptionis. Documentos, Chancelaria e Cultura no Mosteiro de Santa Cruz de Coimbra (Séculos XII a XIV), Coimbra, 2007, p. $142-143$.

${ }^{27}$ A. FRIAS, op. cit. (n. 25), p. 22; S. GOMES, op. cit. (n. 26), p. 158-159; A. GONÇALVES, Novas hipóteses acerca da arquitectura românica de Coimbra, Coimbra, 1938, p. $23-24$.

${ }^{28}$ M. BARROCA, Epigrafia Medieval Portuguesa (862-1422), II-1, Lisboa, 2000, p. 183-187.

${ }^{29}$ A. GONÇALVES op. cit. (n. 23), p. 161; A. GONÇALVES, op. cit. (n. 26), p. 73-74.

${ }^{30}$ S. GOMES, op. cit. (n. 25), p. 155-156.

${ }^{31}$ Ibidem, p. 156; R. SANTOS, O Românico em Portugal, Lisboa, 1955, p. 38.
} 
his lineage - inside a locus sanctus that would preserve his eternal memory, a regal pantheon that mimicked those that Fernando the $1^{\text {st }}$ and Afonso the $6^{\text {th }}$ had built in León and Sahagún, as we've seen before, underlining his status as an equal to the kings from which he had been a dependent and subject; and, on the other hand, to assert the choice of the Augustinians in order to counterbalance the enormous influence of the Cluniac's on the court of Alfonso the $7^{\text {th }}$ and of the archbishoprics of Toledo and Santiago de Compostela, with the obvious purpose of ensuring a greater independence for the Portuguese Church in the Iberian context and before the Holy See.

The earliest burial performed at Santa Cruz, probably already at the monastery's galilee, was that of D. Matilde (or Mafalda), the first wife of Afonso Henriques, dead in 1157. In 1163 the first abbot Teotónio, dead in 18 February 1162, was canonized $^{32}$, confirming the status of Santa Cruz as locus sanctus but also justifying the increasing afflux of pilgrims and other faithful to the church ${ }^{33}$. The king himself died in 1185 , and would be laid to rest in the same galilee, the first royal pantheon of the Portuguese monarchy, being followed in his example by his son king Sancho the $1^{\text {st }}$, dead in 1211. The latter would also rest alongside his family, a setting for which he would leave in his first testament, of 1188, an endowment of 400 silver marks for the «ornamentation of the church» ${ }^{34}$, together with a solid gold cross, adorned with pearls and precious stones and carrying a piece of the Holy Cross $^{35}$. Several other infants and descendants of the royal family would find their burial place in this galilee, before the following kings decide to switch the royal pantheon to the new and imposing monastery that the Cistercians would finished by the middle of the $13^{\text {th }}$ century: founded in 1153, it would only be completed about a century later in Alcobaça, where kings Afonso the $2^{\text {nd }}$ and Afonso the $3^{\text {rd }}$, with their families, would be later buried, a token of the decreasing influence of Augustinians and Cluniacs and of the rise of the Cistercians of Saint Bernard.

The project of Santa Cruz of Coimbra, amongst the most monumental religious constructions in the young kingdom, was probably directed by the same Robert, of Auvergnate origin, that would also work in the Coimbra and Lisbon Cathedrals, here helped by Master Soeiro ${ }^{36}$. Bringing from his birth region the idea of the narthex or galilee preceding the church - not necessarily of funerary use, as in NotreDame-du-Port in Clermont-Ferrand, or Saint-Pierre and Saint-Caprais of Mozac ${ }^{37}$ - the affinities with the churches with galilees like Cluny II, Romainmôtie ${ }^{38}$ or Tournus ${ }^{39}$ were nevertheless undeniable.

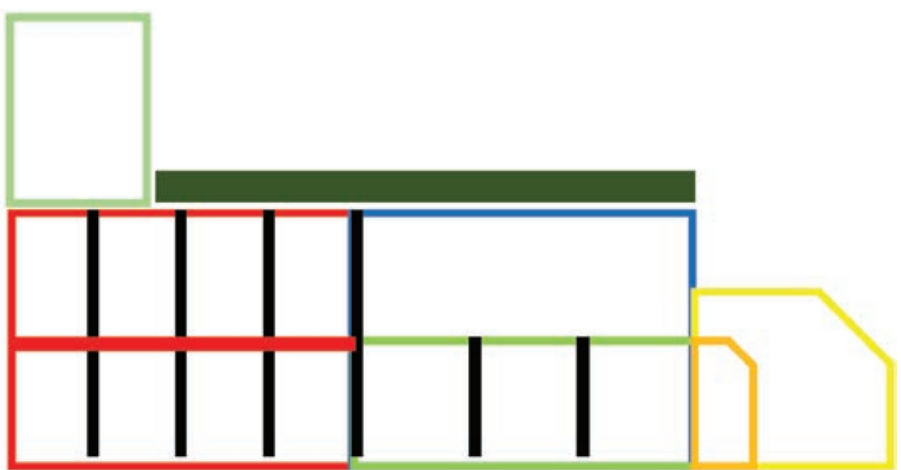

Fig. 3 - Santa Cruz of Coimbra, Portugal, graphic restitution of the volumes of the Romanesque church with, in yellow, the chancel and terminal chapels, in blue the main nave, in green the side chapels and the tower and in red the galilee

The $12^{\text {th }}$ century church had a large central nave, covered by a barrel vault and having 3 chapels on each side, also covered by barrel vaults but placed transversally, as in the galilee of Tournus, communicating with the central nave through wide round arches and thus giving the sensation of a 3 aisles body, almost as long as wide. It was preceded by a galilee of the same length and width of the main nave, with three aisles and four bays, with the crypt for royal burials on the ground floor, and probably a chapel - of the dead - in the upper one, as in the Burgundian churches or San Isidoro of León; the chancel presented obvious similarities with that of Saint Rufus of Avignon ${ }^{40}$. It is today difficult to fully assess the original plan of church and galilee, over which front a tower would rise (fig. 3), since it was replaced by a $16^{\text {th }}$ century construction that, nevertheless, preserved the original perimeter of the architectonic ensemble, as the archaeological research developed throughout the $20^{\text {th }}$ century clearly proved.

\section{THE GALILEES IN THE KINGDOM OF PORTUGAL: SPREADING THE MODEL}

This model was later followed in several $11^{\text {th }}$ to early $13^{\text {th }}$ centuries foundations throughout the northwest of Portugal, all simple single nave churches, mostly monastic, that mirror the limited scale of most religious constructions on these early stages of the kingdom's setting. Amongst them, we must point out the examples of:

- Santa Cristina [Saint Christine] of Serzedelo, near Guimarães, where the oldest epigraph carved into the exterior side walls of the temple relates to a Galindo Gonçalves, of the Riba-Cávado gentry, dated 1071 or $1072^{41}$, although the ensemble of the church and its gali-

\footnotetext{
$\overline{3^{2}}$ M. BARROCA, op. cit. (n. 28), vol. II-1, p. 288-291; A. GONÇALVES op. cit. (n. 23), p. 175.

33 S. GOMES, op. cit. (n. 26), p. 41.

${ }^{34}$ S. GOMES, op. cit. (n. 24), p. 284-285; J. SILVA, Da Galilé à Capela-mor: o percurso do espaço funerário na arquitectura gótica portuguesa, in O fascínio do fim, Lisboa, 1997, p. 45-59, here p. 47.

35 A. GONÇALVES, Estudos de Ourivesaria, Porto, 1984, p. 61-66; C. ALMEIDA História da Arte em Portugal. O Românico, 3, Lisboa, 1986, p. 174-175; A. MIRANDA, Imagens do sagrado na iluminura e ourivesaria românicas em Portugal, in J. Valle Pèrez, J. Rodrigues (ed.), Românico em Portugal e Galiza, Lisboa/Corunha, 2001, p. 185-213, here p. 204 e M. BARROCA, op. cit. (n. 28), II-1, p. 667-670.

${ }^{36}$ A. GONÇALVES, op. cit. (n. 26), p. 151-156.

${ }^{37}$ A. GONÇALVES, op. cit. (n. 23), p. 191-205, here p. 202-205.

${ }^{38}$ M. REAL, A organização do espaço arquitectónico entre Beneditinos e Agostinhos, no séc. XII, in Arqueologia 6, Porto, 1982, p. 118-132, here p. 125; M. REAL, O Convento Românico de S. Vicente de Fora, in Monumentos, 2, Lisboa, 1995, p. 14-23, here p. 17.

${ }^{39}$ C. ALMEIDA, op. cit. (n. 35), 3, p. 115; C. ALMEIDA, História da Arte em Portugal. 1 O Românico, Lisboa, 2001, p. 131.

${ }^{40}$ A. GONÇALVES op. cit. (n. 23), p. 169; M. REAL, op. cit. (n. 37), p. 124-125; M. REAL, op. cit. (n. 37), p. 19-21.

${ }^{41}$ M. BARROCA, op. cit. (n. 28), II-1, p. 102-105.
} 


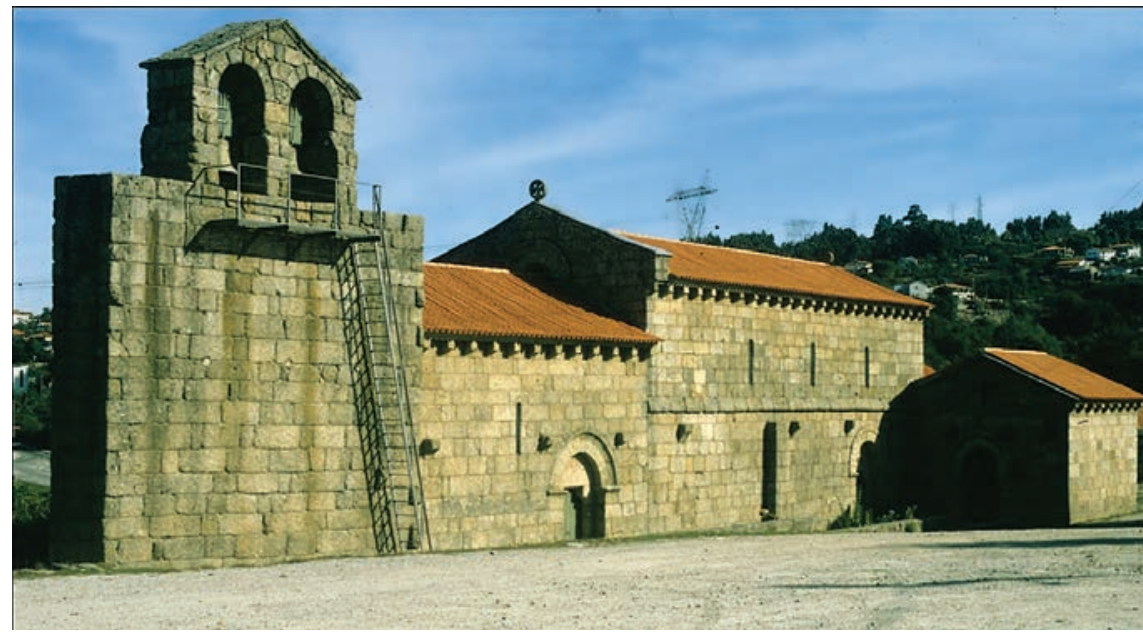

Fig. 4- Santa Cristina of Serzedelo, Guimaräes, Portugal, church and galilee

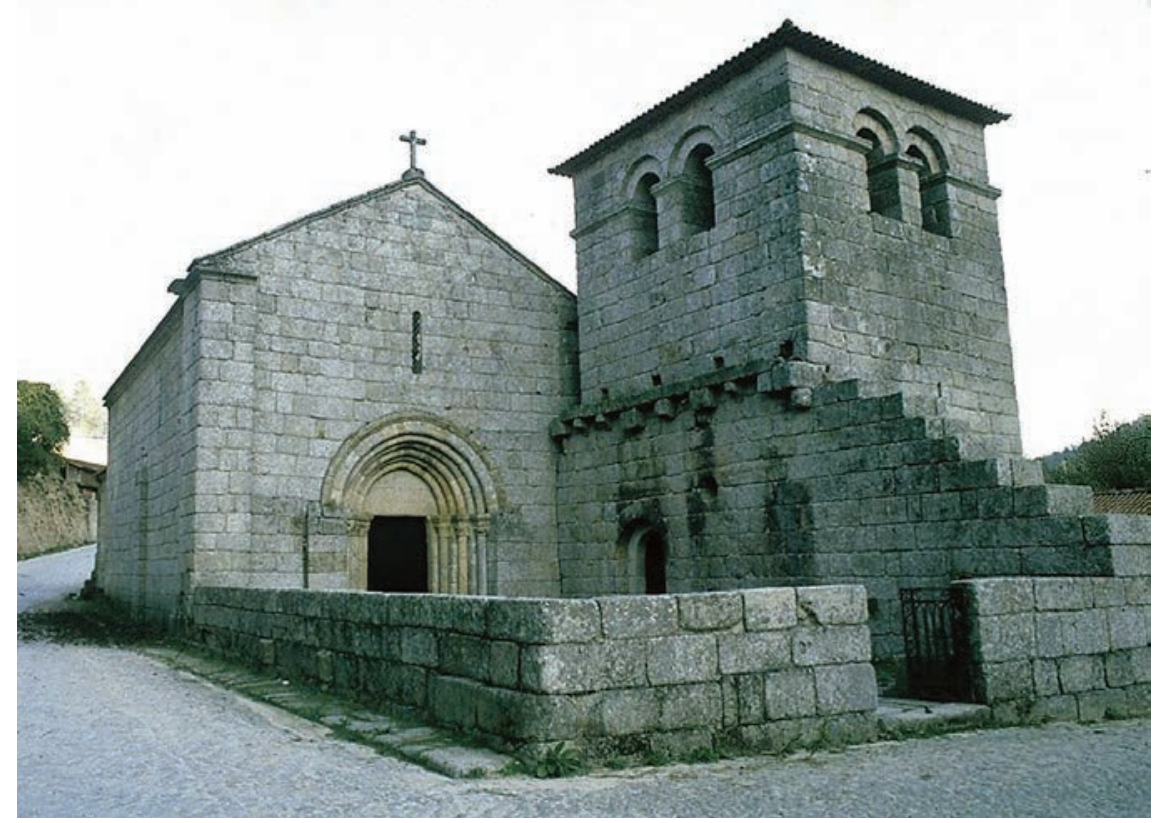

Fig. 5 - São Salvador of Freixo de Baixo, Amarante, Portugal, church preceded by the space of the destroyed galilee

lee, with two arcosolia still preserved, on the northern inside wall, was not finished before the beginning of the $13^{\text {th }}$ century (fig. 4);

- São Miguel [Saint Michael] of Vilarinho, in Santo Tirso, first mentioned in 1120 in the Bula Officii Mei by Pope Calixtus the $2^{\text {nd }}$ as the «monasterium of Villarinho»; a funerary inscription dated 1168, and its ties to the Fafes gentry seem to place its construction between around 1170 and the early years of the following century ${ }^{42}$. The galilee is, on this case, also intact but bearing only one arcosolium, and presenting a southern wall that seems to have been rebuilt at a later stage;

- São Martinho [Saint Martin] of Mancelos, in the vicinities of Amarante, also an early $13^{\text {th }}$ century building, with a galilee preceding the nave having on its south side a tower that seems to have performed more than just a support for the bells, is in fact documented since the beginning of the previous century, as early as 1120 or $1131^{43}$. Besides the burial space of the galilee, there is also another sarcophagus placed inside a separate arcosolium on the outer face of the church's southern wall, testifying to the importance of the privileged burials at this time in the young kingdom;

Salvador [Saviour] of Freixo de Baixo, also in the Amarante area, alongside the road to Lixa, set in the lower part of the village and isolated from it, is all that's left of the ancient monastery, founded still on the $11^{\text {th }}$ century, around 1090 or $1091^{44}$, and apparently refounded in $1120^{45}$. A temple of very simple build, dating from the late $12^{\text {th }}$ or early $13^{\text {th }}$ centuries, it still preserves - as in Mancelos - the strong corner «bell» tower on the south side, beside the space of the now open sort of «atrium», where the galilee once stood (fig. 5), as we can still infer reading the description in a document dated 1715, a «Mediçam da lgreja, Caza do Cura \& mais pertenças», that would roughly translate as the «Measurement of the House of the Priest and other assets», where is mentioned the "Galilê que estâ descuberta na emtrada» [the galilee that is unroofed at the entrance], something that the travelling chronicler Francisco Craesbeeck will confirm in $1726^{46}$.

\section{TWO CASE STUDIES: SÃO PEDRO OF FERREIRA AND SANFINS OF FRIESTAS}

The most interesting of the rural churches preceded by a galilee - or what's left of it - are, nevertheless, those of São Pedro [Saint Peter] of Ferreira, in Paços de Ferreira, not far from Oporto, and the isolated monastic church of Sanfins of Friestas, near Valença, in the farther northern border of the country.

São Pedro [Saint Peter] of Ferreira, a former Augustinian monastery church, closely connected to the Chapter of the Oporto Cathedral since 1195, is a good example of a restoration work that did not go well. With a convulsed and controversial history, the foundation of the monastery was attributed by several authors to a military order such as the Templars or even the Knights of the Holy Sepulchre: the confusion seems to have its roots on a misreading of the Inquirições of Afonso the $3^{\text {rd }}$, dated 1258 , where it is said that «interrogatus cujus est ipsum Monasterium, dixit quod est Militum et Divitum hominum» ${ }^{47}$; the expression Militum,

\footnotetext{
${ }_{42}$ www.csarmento.uminho.pt/amap_4139.asp; A. COSTA, Corografia Portuguesa, I, Braga (2ª ed.), 1868 , p. 99.

${ }^{43}$ A. REUTER, Chancelarias Medievais Portuguesas. Documentos da Chancelaria de D. Afonso Henriques, I, Coimbra, 1938, p. 48; B. SOUSA, Ordens Religiosas em Portugal. Das origens a Trento - Guia Histórico, Lisboa, 2005, p. 190.

44 M. BARROCA, op. cit. (n. 28), vol. II-2, p. 1870.

${ }^{45}$ M. OLIVEIRA, As Paróquias Rurais Portuguesas, Lisboa, 1950, p. 19o, quotes two documents, one dated 1091 and the other 1120 that mention the monastery, published respectively in P. M. H., Diplomata et Chartae, n. 746, and the Censual do Cabido da Sé do Porto, Porto, 1924, p. 4, in accordance with the Boletim da DGEMN - Igreja de Freixo de Baixo, 92, Lisboa, 1958, p. 5, although here the Foundation is wrongly attributed to the Augustians.

${ }^{46}$ F. CRAESBEECK, Memórias ressuscitadas da Província de Entre Douro e Minho no ano de 1726, I, Ponte de Lima, 1992, p. 359.

47 Portugaliae Monumenta Historica [P.M.H.] Inquisitiones, vol. I, part. I, Olisipone, 1888, p. 562.
} 


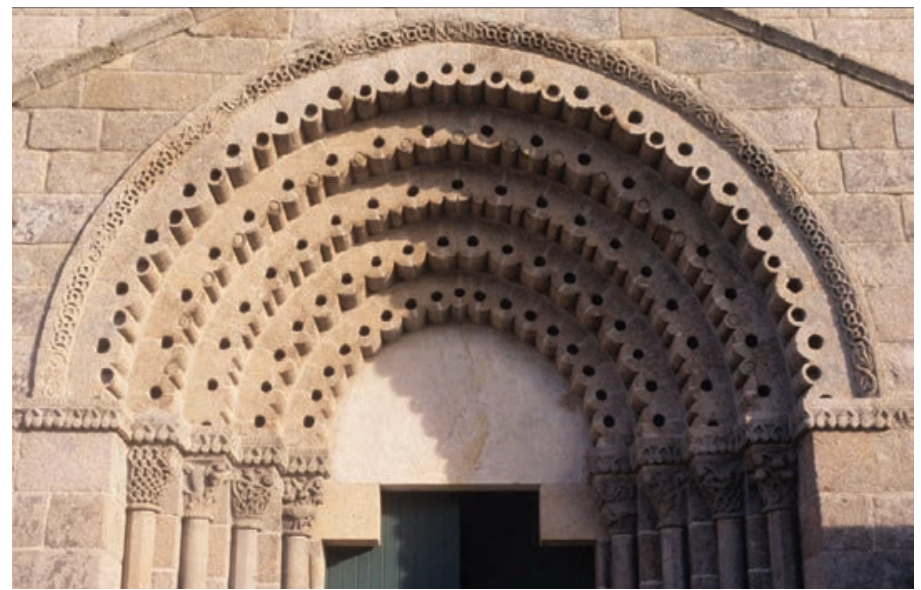

Fig. 6-São Pedro of Ferreira, Paços de Ferreira, Portugal, aspect of the main portal

nevertheless, did not refer to the knights of a military order but to any laic knight, that is to say, to those that were bearers of arms and with social status to ride a horse ${ }^{48}$. In 1182 its prelate bore already the title of Abbot, with the institution of a Collegiate at the church.

The chronology of the erection of the church of Ferreira is known with some precision, with a documented group of 20 masons - stonemasons and martlets - working in a continuous period between $1180-1182$ and 1195, what helps to explain the quality and overall coherence of the architecture of a church that is probably the best built in all the Portuguese Romanesque. Although the galilee was only finished sometime later, it must have made part of the original plan that involved three mason masters from Zamora, Coimbra and the Oporto region ${ }^{49}$. Some influences from Galicia, not only in the architecture - with an unusually tall elevation of the church for the Portuguese Romanesque - but also in the sculpture, are clearly apparent, reminding us of buildings like Santa Eulalia de Donas, Santa Maria de Tomiño or San Salvador de Albeos.

With a main portal clearly influenced by that of «el Obispo» from Zamora cathedral50 (fig. 6), but also related to those of the churches of San Tomé or Santiago del Burgo, also in Zamora ${ }^{51}$, the remaining decoration, and even the lost but partially rendered tympanum of said main portal, seem more related to the Romanesque architecture of the region of Braga, including that of its Cathedral and of the Saviour of Arnoso, or to the ornamentation of the nearby church of Unhão, bearing the motif of the inscribed cross ${ }^{52}$.

The restauration of 1937 failed to identify the original function of the unroofed space in front of the church's façade as the ante-church or galilee of funerary intention (fig. 7), as in Santa Cristina de Serzedelo, S. Miguel de Vilarinho or Freixo de Baixo. Preserved in its current fashion of a midheight wall - with no parallel in any known example of the architecture of the period - it contributed to the false idea of a «fortified» temple that lasted until new research was conducted in recent years ${ }^{53}$.

This galilee, which we can date from around $1232^{54}$, today unroofed and with the walls totally disfigured, was formed of two consecutive segments: one shorter and narrower, but with much thicker walls, on the western side; and one longer and wider, with thinner walls and leading to the main portal

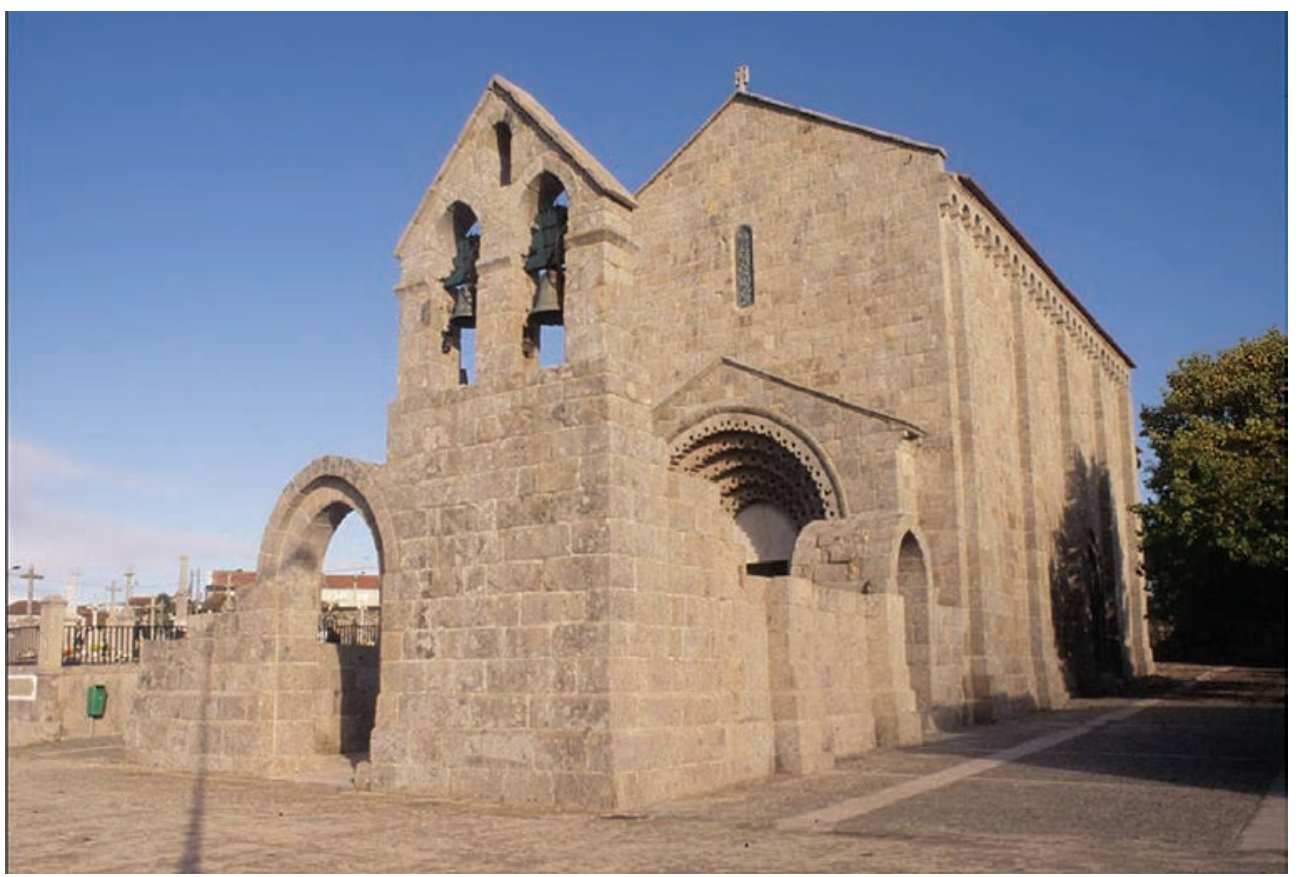

Fig. 7 - São Pedro of Ferreira, Paços de Ferreira, Portugal, church and the misinterpreted of the former galilee, unroofed

\footnotetext{
$\overline{4^{8}}$ M. REAL, A Igreja de S. Pedro de Ferreira. Um invulgar exemplo de convergência artística, Paços de Ferreira, 1986, p. 245-294, here p. 252 and 254; J. MATTOSO, op. cit. (n. 22), II, p. 174 also spelt milites or miles.

${ }^{49}$ M. REAL, op. cit. (n. 48), p. 263-273 and 277-287 ss.

${ }^{50}$ M. BARREIROS, A Igreja Românica de S. Pedro de Ferreira, in Ilustração Moderna 19, Porto, 1928, p. 158-171 and n. 20, p. 28-35, here p. 34.

${ }^{51}$ M. REAL, op. cit. (n. 48), p. 264.

${ }^{52}$ M. REAL, op. cit. (n. 48), p. 263-265 and 273-274.

${ }_{53}$ M. REAL, op. cit. (n. 48), p. 245-294; J. RODRIGUES, Galilea, locus e memória. Panteões, estruturas funerárias e espaços religiosos associados em Portugal, do início do século XII a meados do século XIV: da formação do Reino à vitória no Salado, Lisboa [PhD thesis], 2011, p. 162-187.

${ }^{54}$ M. REAL, op. cit. (n. 48), p. 286, the date of the will of the clergyman Gonçalo Gonçalves from Guimarães.
} 


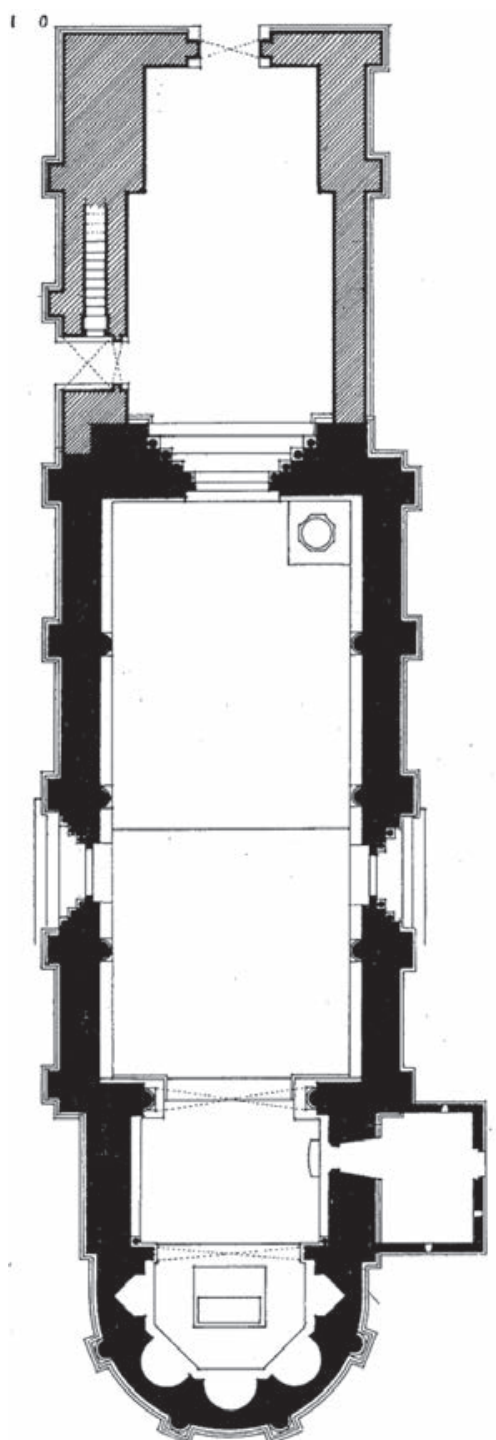

Fig. 8 - Säo Pedro of Ferreira, Paços de Ferreira, Portugal, plan of the church and galilee after restoration [after Boletim da $\operatorname{DGEMN}(1958), n^{\circ}$ 92]

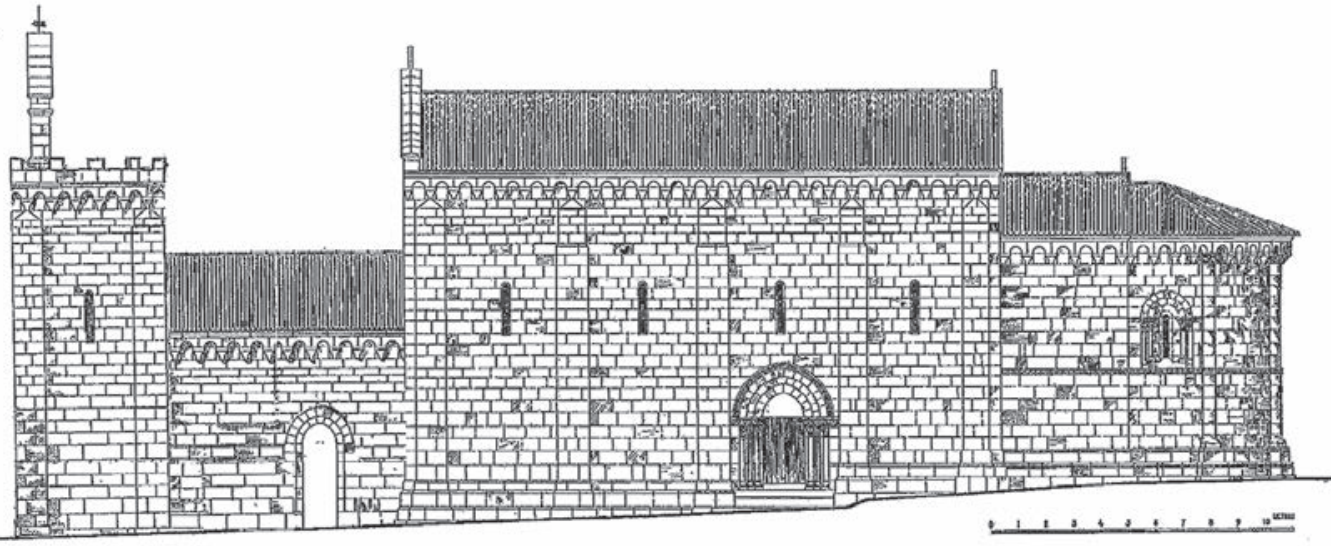

Fig. 9 - São Pedro of Ferreira, Paços de Ferreira, Portugal, graphic restitution of the elevation of the church and galilee [based on Boletim da DGEMN (1958), no 92]

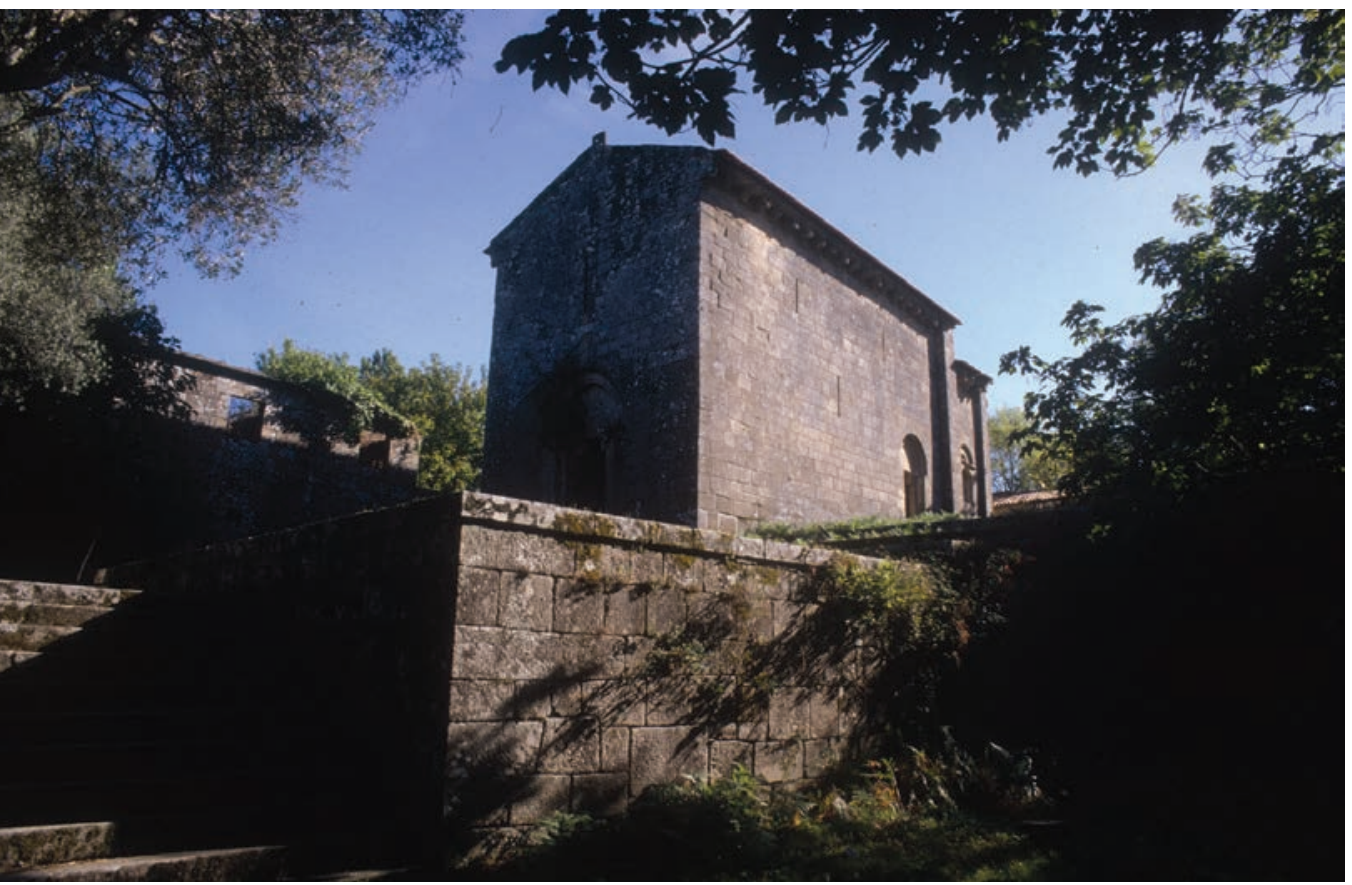

Fig. 10 - Sanfins de Friestas, Valença, Portugal, general view of the church today, deprived of the galilee of the church that it then concealed. A staircase, hidden inside the wall and uncovered during the restoration works, lead to a now missing upper floor (fig. 8).

The combined thickening of the wall and the staircase that today «leads to nowhere», are not only a solution often found on the French Romanesque ${ }^{55}$, but also one which gets us closer to the prototype of the model found in the original house of the Portuguese Augustinians, that of Santa Cruz de Coimbra. The original church presented a tower over the main façade, a solution probably adopted also in Ferreira, explaining not only the need for thicker walls but also for the staircase, leading to the upper level with, most likely, a chapel of the dead at its middle level, and a battlement - and probably the bells - on its top (fig. 9).

On a completely different location stands the monastery of Sanfins de Friestas, on the top of a hill dominating the plane that spreads down to the banks of the river Minho, natural border between Portugal and Spain. Erected on an isolated place, it probably betrays its origins, standing over the foundations of a former eremitic community, an assumption based on its patron - San [Saint] Fins, or Saint Fins the Old One $e^{56}$, from which the simplified Sanfins form will derive - but also on its secluded setting, making it hard to ensure the subsistence of the monastic community on such a rough environment, only justifiable by a symbolic need of occupation of such a high place, probably previously known for its pagan or heterodox rituals.

The establishment of the monastery, in the beginning of the $12^{\text {th }}$ century, is due to Afonso Henriques, at around $1134^{57}$ as a Benedictine foundation, followed by other benefits in 1172 , confirmed in 1190 by Sancho the $1^{\text {st }}$ and in 1221 by Afonso the $2^{\text {nd } 58}$. An epigraph engraved in two stone ashlars, now

55 L. CABRERO-RAVEL, Traitement et fonction des massifs de façade auvergnats, in Ch. Sapin (dir.), op. cit. (n. 5), p. 168-179, here p. 171-173; K. KRÜGER, op. cit. (n. 7), p. 419.

${ }^{56}$ M. COSTA História do Bispado e Cidade de Lamego II. Idade Média: paróquias e conventos, Lamego, 1979, p. 152-154.

${ }^{57}$ R. Azevedo, A. Costa (ed.), Documentos Medievais Portugueses. Documentos particulares A.D. 1116-1123, I.1, Lisboa, 1980, doc. 142, p. 165-166; A. REUTER, op. cit. (n. 43), I, p. 78-79.

${ }_{58}^{5}$ J. RODRIGUES, O Mundo Românico, in P. Pereira (dir), História da Arte Portuguesa, I, Lisboa, 1995, p. 180-331, here p. 222. 


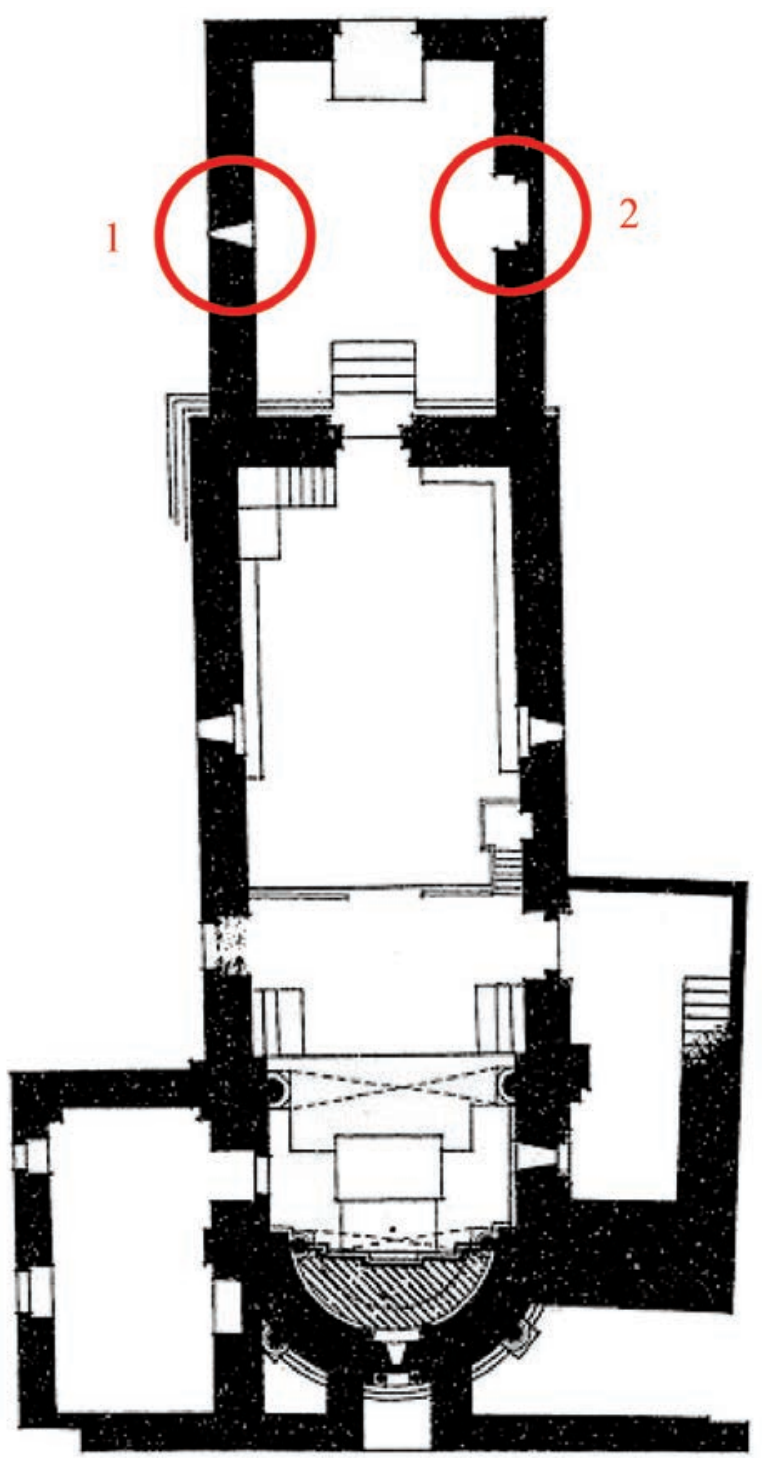

Fig. 12 - Sanfins de Friestas, Valença, Portugal, plan of the church and galilee with the louver (1) and arcosolium (2) signalled [based on Boletim da DGEMN (1938), no 11]

lost ${ }^{59}$, displayed the date of 1221 , probably corresponding to the year of conclusion of the galile $e^{60}$, destroyed during the restoration works of the 1930's due to an error of interpretation that considered another memorial panel, showing the date of 1780 , over the main door of said ante-church ${ }^{61}$.

The church has a single nave of uncommon height, with obvious Galician influences, as in Ferreira (fig. 10). The access to the temple is possible through three doors - axial, north and south - with some interesting sculptural elements, like the tympanum of the main portal, previously concealed by the galilee as in Ferreira, sporting an intricate incise ophidian ornamentation, that snakes between half-circles, zigzags, denticulate and wavy motifs, in a recollection of the former Iron Age decoration of the «Castreja» culture from the Northwest of the Iberian Peninsula (fig. 11).

But it's mainly the galilee that we are interested in, with an obvious medieval construction of pseudo-isodic granite

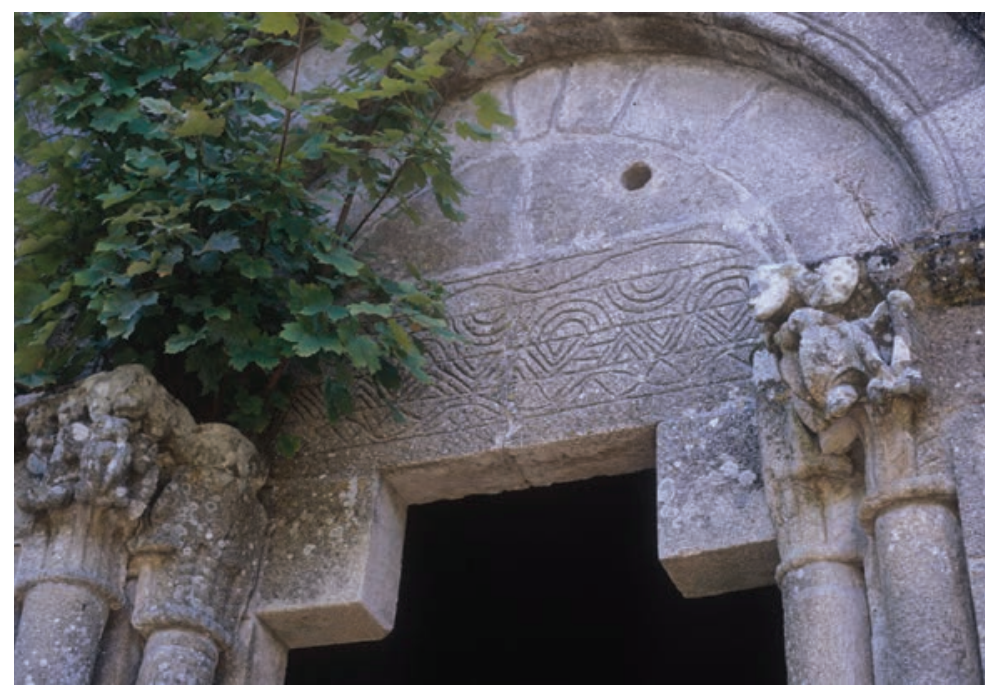

Fig. 11 - Sanfins de Friestas, Valença, Portugal, the tympanum of the main portal

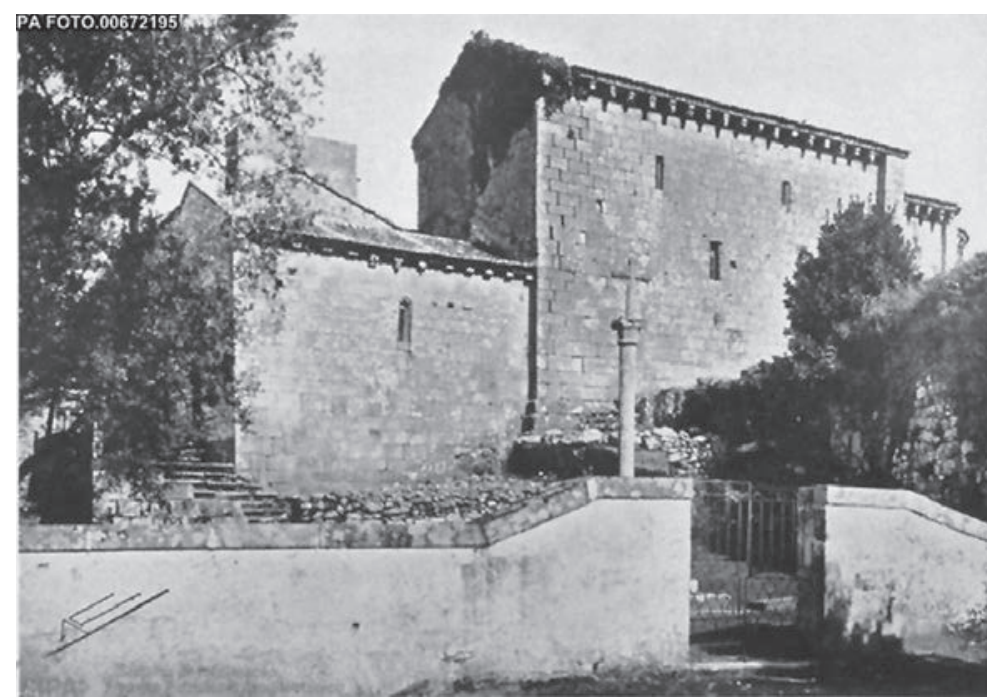

Fig. 13-Sanfins de Friestas, Valença, Portugal, view of the church and galilee before the destruction of the later in the 1930's [after Boletim da DGEMN (1938), no 11]

ashlars, still sporting, at the time of its careless destruction, a narrow louver on the south wall and an arcosolium on the interior of the opposing wall, as in Serzedelo or Vilarinho, stating its obvious burial function (fig. 12). We know very little more about this construction that, judging by one of the few photographs available (fig. 13) presented an obvious accordance with the masonry of the church, with a single entrance on its western façade, here compensating for the uneven level of the ground in front of the temple, as in Vilarinho, by a flight of stairs.

\section{FOR A CONCLUSION}

We knew from the start that many of the architectonic structures still preserved, preceding the façade of many of the surviving Portuguese Romanesque temples, had been misinterpreted at the time of the restoration works performed mainly on the first half of the $20^{\text {th }}$ century, which we

59 M. BARROCA, op. cit. (n. 28), vol. II-1, p. 703.

${ }^{60}$ M. REAL, op. cit. (n. 48), p.129; C. ALMEIDA, op. cit. (n. 35), 3, p. 54.

${ }^{61}$ Boletim da DGEMN - S. Fins de Friestas, 11, Lisboa, 1938, p. 21 and figs. 14 and 15; J. RODRIGUES, A Direcção-Geral dos Edifícios e Monumentos Nacionais e o restauro dos monumentos medievais durante o Estado Novo, in Caminhos do Património, Lisboa, s.d. [1999], p. 69-82, here p. 76; M. REAL, op. cit. (n. 48), p. 129-130, where the Author tries to prove a closer affinity to the model of Santa Cruz de Coimbra, including in what concerns the existence of an upper storey - a chapel of the dead - that is not totally apparent in the images available. 
had already come across in several other occasions. Taking as starting point the example of the first regal pantheon of the Portuguese kingdom under formation - that of Santa Cruz of Coimbra - we then proceeded to explore its «lineage» in a dominion that remained, at the time, mainly rural and struggling to overcome the overwhelming presence of the Muslim occupation on most of its current territory. In places like Santa Cristina of Serzedelo, S. Miguel of Vilarinho or S. Martinho of Mancelos these medieval galilees are still kept more or less intact and in situ, but in many other places, like S. Pedro of Ferreira or Sanfins de Friestas, as we have just seen, the archaeological and architectonic evidence has been severely overshadowed, when not destroyed altogether; in other places, like in Salvador of Freixo de Baixo, they were ignored and «scenographically» arranged. Nevertheless, both in architectural as in symbolic terms, these structures are of primary importance, given the crucial role they played in the evolution of the burial rites at the Portuguese monasteries during the $11^{\text {th }}$ to early $13^{\text {th }}$ centuries, echoing the same use and rituals performed at the other Peninsular kingdoms and beyond the Pyrenees. In addition, that was our main motivation to try to restore them to their former glory - even if, in many cases, only through a process of virtual recreation - always within the strict boundaries of the historical, archaeological and artistic data we are able to collect and confirm.

It becamealmost immediately apparent that the evolution of this specific kind of architecture was madeaccording to the need, on the part of the buried, of a greater symbolic liaison but also some kind of dependence towards the churches to which these galilees are physically attached, seeking their patrons and promoters an obvious approach to the monastic temples, buried in clearly privileged spaces that established a radical contrast with the «common» burials, thus enhancing their main goal: the perpetual evocation of their memory. 